\title{
Zbrodinia
}

\section{w starych dekoracjach - historyczne powieści kryminalne Jakuba Szamałka}

Powieść kryminalna jest bez wątpienia jedną z najdynamiczniej rozwijających się obecnie literackich konwencji gatunkowych, a jej odmiana, kryminał historyczny, cieszy się niesłychaną popularnością ${ }^{1}$. Robin W. Winks we wstępie do zbioru tekstów poświęconych tej formie ${ }^{2}$ usiłuje odpowiedzieć na pytanie o powody takiego czytelniczego entuzjazmu. Odnotowując wielość przyczyn zjawiska stwierdza, że opowieści, w których tematem jest dochodzenie do wiedzy o okolicznościach zbrodni i motywach sprawców, osadzone w historycznej przeszłości, mają dla czytelników nieprzeparty urok dlatego, że przywracają rozwiązywaniu kryminalnych zagadek ich pierwotny wdzięk: $z$ dala od procedur śledczych, komputerowych rekonstrukcji i spektograficznych analiz bohater jako detektyw, poszukiwacz prawdy, stara się odpowiedzieć na pytanie, kto zabił i dlaczego. Nadto, realia dalekie od świata, w którym żyją odbiorcy, pozwalają im zbudować

*Uniwersytet Łódzki, Katedra Teorii Literatury, e-mail: agniz@poczta.onet.pl.

${ }^{1}$ Zob. P. Kaczyński, Kryminał historyczny - próba poetyki, [w:] Literatura kryminalna. Śledztwo w sprawie gatunków, red. A. Gemra, Kraków 2014, s. 191; też R. W. Winks, Preface, [w:] The Detective as Historian: History and Art in Historical Crime Fiction, ed. R. B. Browne i L. A. Kreiser, Jr, Bowling Green, 2000, s. ix.

${ }^{2}$ Winks używa tu zresztą terminu „historical mystery”, najczęściej pojawiającego się w anglojęzycznych tekstach dotyczących kryminału historycznego (Preface, s. xi). Określenie „mystery” odnosi się do klasycznej postaci powieści detektywistycznej; zob. np. M. Czubaj, Etnolog w Mieście Grzechu. Powieść kryminalna jako świadectwo antropologiczne, Gdańsk 2010, s. 32. Wikipedia odnotowuje również inne określenia tej konwencji: "historical whoduit" [online] https://en.wikipedia.org/wiki/Historical_mystery (dostęp 14.08.2016). Określenie „historical crime fiction”, występujące w tytule książki z przedmową Winksa, jest relatywnie rzadko używane w literaturze przedmiotu.

Nawiasem mówiąc, ukazał się też kolejny tom owej antologii: The Detective as Historian: History and Art in Historical Crime Fiction Volume II, ed. R. B. Browne i L. A. Kreiser, Jr, Newcastle 2007. 
bezpieczny dystans wobec owych "historycznych" zbrodni i ich okoliczności, jakkolwiek krwawe i brutalne by one nie były, a co za tym idzie, czerpać z lektury intelektualną przyjemność czystszą niż w przypadku opowieści współczesnych ${ }^{3}$.

Paweł Kaczyński, podejmując próbę zdefiniowania tej konwencji, przywołuje stosowane głównie przez polskich wydawców, rzadziej literaturoznawców, rozróżnienie na kryminał retro i kryminał historyczny. Za wyznacznik tego ostatniego uznaje osadzenie akcji w czasach sprzed narodzin nowoczesnych instytucji policyjnych i pojawienia się agencji detektywistycznych ${ }^{4}$. Kaczyński uznaje, że opisywana przez niego konwencja jest hybrydą dwóch gatunków: powieści kryminalnej i historycznej ${ }^{5}$, zatem poza intrygą skonstruowaną wokół popełnionej zbrodni, forma ta oferuje czytelnikowi pewien zasób wiedzy o przeszłości historycznej ${ }^{6}$. Jego zdaniem istotnym elementem kryminału historycznego jest konstrukcja głównego bohatera oparta na anachronizmie - centralna postać obdarzona jest bowiem wiedzą i dociekliwością kogoś, kto czytał Conan Doyle'a i Agathę Christie, nastawieniem nieprzystającym do realiów, w których prowadzi śledztwo 7 . Wedle piszącego, konieczność uprawdopodobnienia owych detektywistycznych predylekcji protagonisty prowadzi do kolejnych modyfikacji świata przedstawionego, również sprowadzających się do anachronizmów:

Próby wniknięcia w umysłowość człowieka dawnej epoki i unikanie prezentyzmu zderzają się w konwencji kryminału historycznego z konstytutywnym anachronizmem sytuacji śledztwa i kreacji postaci detektywa ${ }^{8}$.

Kaczyński stwierdza również, że autorzy kryminałów historycznych zdają sobie doskonale sprawę z owej aporii, dlatego tak często zamieszczają w swoich powieściach nie tylko paratekstowe komentarze dotyczące samej konwencji, ale i wplatają $\mathrm{w}$ ich teksty rozmaite intertekstualne gry odsyłające do klasyki powieści kryminalnej ${ }^{9}$. Zabiegi te budują metatekstowy poziom wielu opowieści powstałych $\mathrm{w}$ ramach konwencji.

Nie wdając się $\mathrm{w}$ rozbudowane komentarze do powyższych uwag wypada stwierdzić, że anachronizm jest cechą konstytutywną powieści historycznej. Element ten zostaje wzmocniony w wypadku kryminału historycznego chęcią zaangażowania emocjonalnego czytelników w komplikacje - z definicji obcego wszak (bo przeszłego) - świata i działającego

\footnotetext{
${ }^{3}$ Zob. R. W. Winks, Preface..., s. xi.

${ }^{4}$ P. Kaczyński, Kryminał historyczny..., s. 191-192.

${ }^{5}$ Tamże, s. 205.

${ }^{6}$ Tamże, s. 197.

${ }^{7}$ Tamże, s. 193.

${ }^{8}$ Tamże, s. 199 .

${ }^{9}$ Tamże, s. 199-200. Osobną kwestią jest zagadnienie metaliterackości jako zjawiska typowego dla pewnego modelu powieści kryminalnej. Pisał o tym Mariusz Kraska, powołując się na George'a Dove'a: „choć [...] autorefleksyjność nie jest esencjalną cechą powieści kryminalnej, to w utworach z okresu Golden Age zyskuje status konwencji operacyjnej, której podstawową funkcją jest »opisywanie lub charakteryzowanie gatunku bez potrzeby jego definiowania «" (M. Kraska, Prosta sztuka zabijania. Figury czytania kryminału, Gdańsk 2013, s. 193).
} 
w nim bohatera prowadzącego śledztwo. Należałoby dodać, że kryminał historyczny odwołuje się najczęściej do klasycznej postaci powieści detektywistycznej - fabuła skoncentrowana jest na protagoniście tropiącym zbrodniarza. Wypada też zauważyć, że dużo częściej inspiracją dla tych postaci są bohaterowie wywodzący się z amerykańskiego czarnego kryminału niż Sherlock Holmes czy panna Marple. Kwestią dyskusyjną jest też, moim zdaniem, rozróżnienie terminologiczne na kryminały retro i historyczne ${ }^{10}$. Proponuję zatem sprowadzenie ich do jednego: kryminału historycznego lub historycznej powieści kryminalnej i określenie tej formy gatunkowej jako hybrydycznego subgatunku powieści kryminalnej, w którym fabuła skonstruowana wokół rozwiązania zagadki kryminalnej osadzona jest w czasie - z perspektywy autora - historycznym ${ }^{11}$. Wreszcie należy dodać, że $\mathrm{w}$ rozmaitych realizacjach przywoływanej tu konwencji gatunkowej różnie układają się proporcje i relacje między jej składnikami prymarnymi - elementami decydującymi o klasyfikacji tekstu jako kryminału, a tymi aspektami świata przedstawionego, które stanowią rekonstrukcję rzeczywistości historycznej. Innymi słowy, w obrębie tego subgatunku mamy do czynienia z tekstami bliższymi powieściom historycznym i takimi, w których sygnały historyczności $i^{12}$ pełnią rolę drugorzędną ${ }^{13}$.

Rozmaite konteksty wyłaniające się przy rozważaniu specyfiki inkryminowanej tu konwencji chciałabym prześledzić analizując trylogię Jakuba Szamałka opowiadającego historię śledztw prowadzonych przez Leocharesa, żyjącego w V wieku p.n.e. (powieści te są ewenementem w polskiej literaturze gatunku, zdominowanej przez teksty, których akcja toczy się w wieku XIX lub w okresie międzywojennym). Akcja pierwszej powieści cyklu Szamałka, zatytułowanej Kiedy Atena odwraca wzrok, dzieje się w 430 roku p.n.e. w Atenach za rządów Peryklesa. Drugi tom, Morze Niegościnne, opowiada historię rozgrywającą się w Panikapajonie, największym mieście Bosporu, greckiej kolonii na Krymie. Wydarzenia przedstawione $\mathrm{w}$ powieści kończącej serię, Czytanie z kości, toczą się w dwóch planach czasowych: w 421 roku p.n.e. na Półwyspie Apenińskim, gdzie w etruskiej Veii Leochares prowadzi swoje ostatnie śledztwo, i w Londynie roku 2015, gdy jego szczątki stają się przedmiotem dochodzenia. W ostatniej części cyklu to czytelnik ma odpowiedzieć na pytanie, kto jest mordercą ${ }^{14}$.

${ }^{10}$ Takie wątpliwości miał również Paweł Kaczyński, podkreślając raczej pragmatyczny niż literaturoznawczo-teoretyczny wymiar takiej klasyfikacji (zob. tenże, Kryminat historyczny..., s. 191).

${ }^{11}$ Zob. L. Picker, Mysteries of History. Sleuthing through the Past [online] http://www.publishersweekly.com/pw/by-topic/new-titles/adult-announcements/article/43024-mysteries-of-history.html (dostęp 30.08.2016); też A. Izdebska, hasło kryminał historyczny, "Zagadnienia Rodzajów Literackich" 2016, t. 59, z. 4 (120).

${ }_{12}$ Zob. K. Bartoszyński, O poetyce powieści historycznej, [w:] tenże, Powieść w świecie literackości, Warszawa 1991, s. 64.

${ }^{13}$ Na przykład w powieści Anny Trojan Jak makiem zasiat, której akcja toczy się u schyłku XIX wieku w bliżej nieokreślonym mazowieckim miasteczku, realia historyczne są bardzo szkicowo zarysowane i nie odgrywają w kryminalnej intrydze nieomal żadnej roli.

${ }^{14}$ Jedno jest pewne: to nie kamerdyner. 
Niejako potwierdzając opisane już pobieżnie cechy konwencji, Szamałek wszystkie powieści cyklu opatruje paratekstowymi komentarzami. We wstępie do Kiedy Atena odwraca wzrok pisze:

Chciałem napisać książkę, po którą sam, jako pasjonat starożytności i powieści kryminalnych miałbym ochotę sięgnąć. Dlatego postawiłem sobie za cel nie tylko wymyślenie wciągającej fabuły, ale też stworzenie postaci, które będą jak najbliższe historycznym realiom - to znaczy myślące i zachowujące się tak, jakby rzeczywiście należały do innej kultury, wyznawały obce nam wartości i hołdowały nieznanym dziś zwyczajom. Zależało mi jednocześnie, aby moi bohaterowie mówili $\mathrm{w}$ jak najbardziej naturalny sposób, a nie wyrażali się jakimś sztucznym, sztywnym językiem pełnym „jednakowoż”, „iżby” i innych „azaliż”, którym w wielu powieściach maskuje się anachronizmy. Starałem się też jak najwierniej zrekonstruować miejsce akcji, opierając się na źródłach pisanych i archeologicznych. Mam nadzieję, że tak przedstawiona starożytność będzie jednocześnie ciekawa i egzotyczna $(K A 9)^{15}$.

W tej wypowiedzi pisarz formułuje zasadnicze dylematy związane z jednym z elementów konwencji: powieścią historyczną. Podkreśla napięcie pomiędzy chęcią zachowania wierności realiom przeszłości, to znaczy pokazania jej jako egzotycznej (wszak „przeszłość to obcy kraj”16), ale jednak w owej odmienności oswojonej, pozwalającej czytelnikowi postrzegać ją jako żywą i w pewnym sensie bliską. Tę bardzo złożoną kwestię sposobu pokazywania przeszłości historycznej w fikcji literackiej bardzo celnie ujął Ryszard Koziołek we fragmencie swego tekstu zatytułowanym znacząco Historia to nie jest kraj dla martwych ludzi. Napisał:

Problem wiarygodności powieści historycznej nie wynika z uzupełnienia fikcją brakujących informacji o przeszłości - historycy też tak robią. Obiektem podejrzenia jest atrakcyjność literackiego ujęcia historii, czyli takiego użycia sztuczek języka (narracji, fabuły, psychologii postaci), że przeszłość przestaje być obcą krainą, zamieszkaną przez istoty mówiące niezrozumiałym językiem, ale przeciwnie - zajmuje czytelnika bardziej, niż jego współczesność ${ }^{17}$.

Prześledźmy zatem, jak Szamałek konstruuje swoją kryminalną opowieść o Leocharesie, człowieku z odległej/martwej/egzotycznej i swojskiej zarazem przeszłości. Przyjrzyjmy się częściom tej trylogii jako swoistym powieściom historycznym.

${ }^{15}$ J. Szamałek, Kiedy Atena odwraca wzrok, Warszawa 2011, s. 9. Wszystkie cytaty w tekście za tym wydaniem, oznaczone skrótem $K A$.

${ }^{16}$ To oczywiście aluzja do znanego tekstu Davida Lowenthala zatytułowanego Przeszłość to obcy kraj, przeł. I. Grudzińska-Gross i M. Tański, „Res Publica” 1991, nr 3, s. 6-22.

${ }^{17}$ R. Koziołek, Kto jeszcze umrze przez Robespierre'a?, [w:] tenże, Dobrze się myśli literatura, Wołowiec 2016, s. 106. 
Zasadniczy zamysł pisarza, widoczny najwyraźniej w pierwszym tomie trylogii, polega na budowaniu obrazu starożytności greckiej w wyraźnej kontrze wobec „olimpijskiej”, narzuconej przez Winckelmanna wizji, wyobrażenia, które utrzymywało się przez cały wiek XIX ${ }^{18}$. Tak więc, według Szamałka, Ateny czasów Peryklesa to nie kolebka cywilizacji euroatlantyckiej, miejsce rozwoju sztuki będącej najdoskonalszym wcieleniem "szlachetnej prostoty i spokojnej wielkości"19, ale smrodliwe i zatłoczone miasto, pełne małostkowych, prymitywnych ludzi, kierujących się nader osobistymi pobudkami. Ów metahistoriograficzny wymiar cyklu został stematyzowany niemal wprost $\mathrm{w}$ ostatnim tomie trylogii, gdy współcześni badacze losów Leocharesa komentują sposób uprawiania boksu w starożytnej Grecji: „Myślałam, że Grecy byli bardziej cywilizowani. - O, nie. Po prostu w dziewiętnastym wieku zrobiliśmy im dobry PR. Wiesz, kolebka europejskiej myśli, sztuki, teatru, i tak dalej. To wszystko prawda... Ale nie do końca" (CK 191) ${ }^{20}$.

Zatem gdy mieszkaniec tego niepodkolorowanego świata, Leochares, udaje się poza granice miasta, doznaje, można by rzec, sensualnej ulgi: „Dobrze było odpocząć i od innych zapachów, od których nie sposób było uciec w Atenach - fetoru zapchanych latryn, pełnego gnijących śmieci Eridanosu, wszechobecnego odoru ludzkiego potu" (KA 78). Otrzymujemy też równie nieupiększony obraz przyjęcia, na którym bawi się elita miasta:

Kiedy wczoraj udało mu się wreszcie wdrapać pod bramę Akropolu, gdzie odbywał się sympozjon, wszyscy byli już równo napruci. Sozjasz, podtrzymywany przez swojego niewolnika, stał przed wejściem i rzygał;... Niketas pieprzył jedną z flecistek, okładając ją przy tym sandałem po pośladkach, a ona zaśmiewała się jak głupia; Filandros leżał pod swoim łożem i deklamował wiersze Archilocha... Perykles z kolei próbował żonglować talerzami, podczas gdy półnaga niewolnica wlewała mu w usta kolejny kielich wina (KA 217).

Ten aspekt swoich powieści Szamałek również komentuje. W Przedsłowiu do Morza Niegościnnego pisze:

Moi Grecy nie są statecznymi filozofami i koneserami sztuki; wzoruję ich na pieprznych ateńskich komediach, przedstawiających ludzi z krwi i kości, a nie na platońskich dialogach, zaludnionych przez wyidealizowanych arystokratów. Choć są od nas różni pod względem kultury, targają nimi te same emocje, mają podobne potrzeby i marzenia, kochają i nienawidzą, potrafią zachować się po chamsku i zakląć. Liczę, że takich właśnie ich Państwo polubią (MN 11-12) ${ }^{21}$.

${ }^{18}$ Zob. W. Bałus, Nowy system wiedzy, [w:] J. J. Winckelmann, Dzieje sztuki starożytnej, oprac. W. Bałus, przeł. T. Zatorski, Kraków 2012, s. XIII.

${ }^{19}$ Tamże.

${ }^{20}$ Wszystkie cytaty w tekście za wydaniem J. Szamałek, Czytanie z kości, Warszawa 2015, oznaczone skrótem CK.

${ }^{21}$ Wszystkie cytaty w tekście za wydaniem J. Szamałek, Morze Niegościnne, Warszawa 2013, oznaczone skrótem $M N$. 
Zatem w tym wypadku nasze czytelnicze emocjonalne zaangażowanie w świat historii Leocharesa ma być oparte na rozpoznaniu podobieństwa raczej, niż na fascynacji odmiennością. Budowaniu takiego nastawienia służy też bez wątpienia język postaci: nader współczesna, soczysta polszczyzna. Odnajdziemy tu więc dialogi następujące: „Po co mi opowiadasz te pierdoły?!... Jeszcze nie skończyłem mówić, zamknij się... Może jesteś zausznikiem tej kurwy Aspazji ${ }^{22}$, ale..." (KA 24-25) oraz spontaniczne reakcje bohaterów: „O żesz kurwa, ja pierdolę!" (KA 158) i niezamierzenie chyba komiczną frazę: „- Cóżże się tu, kurwa, dzieje?!” (MN 163). Otrzymujemy też barwny opis stosunków politycznych Aten z sojusznikami: „Filoksenos był wściekły, mówił, że nie po to nasi dziadowie walczyli pod Maratonem, żebyśmy teraz udupiali, o, tak właśnie powiedział, udupiali wszystkich dookoła. I powiedział... że to hańba, że budujemy te wszystkie świątynie ze składek sojuszników, że za cudze pieniądze to się kurwy, za przeproszeniem, mogą stroić" (KA 172-173). Ten sposób oswajania obcości świata przeszłego najbardziej rzuca się $\mathrm{w}$ oczy $\mathrm{w}$ tomie pierwszym cyklu - wydaje się, że w kolejnych autor moderuje ton postaci, najwyraźniej zdając sobie sprawę z nieco dwuznacznego wdzięku tego zabiegu.

Dopełnieniem owej swojskości jest w powieściach Szamałka konstruowanie egzotyki greckiego świata sprzed wieków. Ową obcość pisarz buduje przede wszystkim na poziomie obyczajowym, w sferze relacji między płciami. Z punktu widzenia współczesnego czytelnika Leochares jest dość prymitywnym mizoginem, uważającym, że jeśli nie bije żony, Lamii, zasługuje na miano małżonka idealnego ${ }^{23}$. Kiedy ogląda stare rzeźby przedstawiające kobiety, jest oburzony: „Jeśli wierzyć kolorom farb, mimo upływu lat nadal widocznym, to musiały nosić makijaż jak najgorsze zdziry z Pireusu... Leocharesowi nie mieściło się w głowie, że jego dziadek wypuszczał tak babcię na ulicę" (KA 86). Innym aspektem owej obyczajowości ukazywanej w powieści są usankcjonowane społecznie relacje homoseksualne. Leochares opiekuje się pięknym młodym niewolnikiem, Demoklesem, który pomaga mu w śledztwie i z którym łączy go dość złożony, choć nie erotyczny związek ${ }^{24}$. Jednocześnie bohater, obserwując w gimnazjonie oznaki upadku obyczajów (niektórzy mężczyźni golą się, by uchodzić za młodszych), wzdycha: „Zeusie, że też widzisz te cioty i nie grzmisz!" (GA 39).

Starożytność grecka czasów Peryklesa w wersji Szamałka to dość prymitywny świat zdominowany przez mężczyzn, rzeczywistość prezentowana

${ }^{22}$ Mowa tu o współtowarzyszce życia Peryklesa, której - jak twierdzą niektórzy historycy - zawdzięczał on, między innymi, swoją pozycję jako polityk.

${ }^{23}$ Rozżalony - można by rzec - feministycznymi fanaberiami żony, która go opuszcza, przeżywa ciężkie chwile: „I zostawiła go - mimo tego, jaki był dla niej dobry, ile na nią łożył pieniędzy! Żony znajomych, jeśli w ogóle wychodziły z domu, to tylko przy wyjątkowych okazjach, na jakiś festiwal albo czyjś ślub, ale żeby ot tak, przyjść na agorę? Ludzie pukali się w głowę, jak o tym mówił. No i on jej nigdy nie uderzył, podczas gdy wszystkie jej siostry ciągle chodziły z podbitymi oczami. I ona mówi o braku szacunku!" (KA 66).

${ }^{24}$ „Tak, to prawda, Leochares miał chętkę na Demoklesa - ale kto nie miał? Chłopak był zjawiskowo wręcz piękny, jakby ulepiony przez bogów" (KA 19). Powstrzymuje go wspomnienie krzyku bólu chłopaka gwałconego w domu publicznym, z którego go wykupił. 
jako piekło kobiet. Agatonika, jedna z sióstr Lamii, jest wiecznie posiniaczona, bita przez starszego od niej o dwie dekady męża. Druga, Killa, jako szesnastoletnia żona rodzi bliźnięta, mało nie przepłacając tego życiem, a potem wykrwawia się na śmierć przy ósmym porodzie: „Postawili jej potem prześliczny nagrobek, z marmuru, na którym wykuto piękną kobietę, nijak do niej niepodobną, przed którą niewolnica otwiera szkatułkę pełną naszyjników, jakich Killa za życia nigdy nie miała" (MN 142-143).

Szamałek podkreśla obcość świata przedstawionego również na poziomie językowo-przedmiotowym. Na przykład w nieco komicznej frazie: „Bardzo śmieszne - rzekł Demokles - Naprawdę, można się w himation ze śmiechu posikać" (KA 15), słowo himation obdarzone jest odsyłaczem do przypisu. Autor powiadamia nas wcześniej, że informacje na temat „realiów, faktów i postaci historycznych oraz nazw geograficznych" czytelnik znajdzie na końcu książki, zaś „dla ułatwienia wszystkie hasła, które nie są nazwami własnymi, oznaczono w tekście gwiazdką" (GA 14). Zatem to rzeczywistość na tyle odległa od realiów, w których żyje czytelnik, że wymaga encyklopedycznych objaśnień. Co więcej, Szamałek osadza swoje kryminalne opowieści w przeszłości historycznej relatywnie mało znanej potencjalnym czytelnikom ${ }^{25}$. Deklaruje wprost ambicje dostarczenia odbiorcom wiedzy na jej temat, szczególnie w drugim tomie cyklu, gdy umieszcza akcję na terenie Bosporu: „Te niezwykłe, egzotyczne rubieże starożytnego świata leżały zawsze na marginesie historii, zapomniane, spowite tajemnicą. Tę tajemnicę chciałbym przed Państwem odsłonić" (MN 11). Zwierza się też z kłopotów wiążących się z owym ujawnianiem: brakiem źródeł historycznych przy obfitości danych archeologicznych, co usprawiedliwia fakt, iż „W niniejszej powieści pojawiają się nieliczne postaci historyczne" (MN 300). Dodaje też, że „Intryga szpiegowsko-kryminalna stanowiąca sedno Morza Niegościnnego jest całkowicie zmyślona - ale muszą Państwo przyznać, że Spartanie byliby szalenie krótkowzroczni, jeśli nie spróbowaliby osłabić

${ }^{25}$ Na przykład dwaj amerykańscy autorzy kryminałów rozgrywających się w czasach rzymskich, Steven Saylor (twórca serii Roma Sub Rosa; polskie tłumaczenia tych powieści zostały zebrane w pięciu tomach: Zagadki Gordianusa, Przygody Gordianusa, Historie Gordianusa, Tajemnice Gordiadusa, Ostatnie sprawy Gordiadusa) i John Maddox Roberts (autor cyklu SPQR, z którego część została przetłumaczona i wydana w Polsce; między innymi Śledztwo Decjusza, Sprzysiężenie Katyliny, Detektyw Cezara) umieścili swych bohaterów w najczęściej chyba pokazywanym w obszarze kultury popularnej okresie historii starożytnej: epoce schyłku republiki (zob też. K. Dominas, Antyk w kryminale, kryminat w antyku. Steven Saylor i recepcja literatury antycznej, [w:] Literatura kryminalna. Na tropie źródet, red. A. Gemra, Kraków 2015, s. 221-241). Z kolei Diana Norman, brytyjska dziennikarka i autorka powieści historycznych, która zasłynęła opublikowaną pod pseudonimem Ariana Franklin serią powieści kryminalnych o Adelii Aquilar, dwunastowiecznej medyczce, każe działać swej bohaterce w Anglii w okresie panowania Henryka II. To świat doskonale znany wielbicielom gatunku i widzom telewizyjnym: wszak braciszek Cadfael, bohater słynnego cyklu kryminałów Edith Pargeter (wydanego pod pseudonimem Ellis Peters i sfilmowanego przez BBC z Derekiem Jacobim w roli głównej), żyje w czasach poprzedzających wstąpienie na tron Henryka Plantageneta - w okresie wojny domowej o sukcesję między zwolennikami króla Stefana i cesarzowej Matyldy. Potencjalni czytelnicy powieści Norman obejrzeli też zapewne którą́s z wersji Lwa w zimie - pasjonującej filmowej psychodramy z życia rodzinnego Henryka II i Eleonory Akwitańskiej (w wersji z 1968, w reżyserii A. Harveya, królewską parę zagrali Katharine Hepburn i Peter O'Toole; w remake'u z 2003 r., autorstwa A. Konczałowskiego, Glenn Close i Patrick Steward). 
najważniejszego żywiciela swego arcywroga..." (MN 301). Te uwagi świadczą o tym, że pisarz bardzo serio traktuje „historyczność" swoich powieści ${ }^{26}$ i ich potencjalne walory poznawcze. $W$ ostatnim tomie, pokazując świat Etrusków, zdaje się też wskazywać, czemu zniknie on w obliczu ekspansji mieszkańców niewielkiej mieściny na Półwyspie - Rzymu.

Jednocześnie Szamałek uprawia również intertekstualne gry podkreślające, że czytelnicy jego powieści obcują przede wszystkim z tekstami literackimi, w których na obraz przeszłości zostały nałożone rozmaite filtry. Temu służy opowieść o wizycie Leocharesa u fryzjera, „który podciął mu włosy, wyrównał brodę i uraczył kilkoma mało zabawnymi dowcipami o Spartiacie, który przychodzi do znachora" (KA 42). Nieco podobną funkcję spełnia zestawienie $\mathrm{w}$ ostatnim tomie trylogii uwagi jednej z bohaterek: "Och, wy archeolodzy klasyczni... kości was nudzą. Nic tylko te wazy, wazy, wazy" (CK 158) z frazą z odautorskiego posłowia: „Na samym początku moich studiów, w 2005 roku dostałem do napisania esej o roli waz w obrządku pogrzebowym starożytnych Greków" (CK 347).

Trylogia Jakuba Szamałka ma zamkniętą, przemyślaną konstrukcję. Wpisany jest $\mathrm{w}$ nią wyraźny zamysł literacki i historiograficzny. Autor rozbudowuje w swych tekstach ten aspekt konwencji, który związany jest z pokazaniem realiów historycznych, umiejętnie splatając go z kryminalną intrygą. Ten wymiar powieści doceniają odbiorcy. Pozwolę sobie przywołać kilka opinii z czytelniczych blogów cytowanych na stronie internetowej poświęconej recenzjom twórczości pisarza (zachowuję oryginalne wersje stylistyczne):

1. Mocną stroną „„Kiedy Atena odwraca wzrok” są wątki historyczne [...] podoba mi się to, że pan Jakub Szamałek nie posłużył się nużącym i ciągnącym się językiem z liczną pulą faktów, dat, nazw miejsc oraz zbędnych opisów [...] 2. Autor zamieszcza więcej ciekawych informacji na temat tamtego czasu co sprawia, że aż chce się czytać tą powieść. Niemalże widziałam walkę kogutów czy sympozjony. Wielu nauczycielom się nie udało zaciekawić mnie tą dziedziną wiedzy, a Jakubowi Szamałkowi jak najbardziej.

3. >>Kiedy Atena odwraca wzrok<< to książka, w której pisarz znalazł sposób na niedowiarków i kręcących nosem na antyczne tematy... Całość skrzy się od efektownych dialogów, nie brakuje scen walki czy elementów, które dziś nazwalibyśmy ezoterycznymi. A więc klasyka kryminału, bez dwóch zdań... Jeżeli jest to początek nowego trendu w powieści historycznej, w której odkurza się historyczne scenerie poszczególnych epok - jestem absolutnie na tak ${ }^{27}$.

${ }^{26}$ Kwestią wymagającą osobnego omówienia - niemieszczącego się w ramach tego tekstu - jest zagadnienie, jak w sposób prawdopodobny pokazać $\mathrm{w}$ kryminale historycznym intrygę wokół poszukiwania sprawców zbrodni w powiązaniu $\mathrm{z}$ „wielką historią". Innymi słowy, jak na przykład złotnik z Aten (Szamałek) czy podrzędny rzymski detektyw z czasów Wespazjana (seria autorstwa Lindsay Davis) ociera się o wydarzenia mogące zmienić bieg dziejów. Idzie tu też o atrakcyjność samej fabuły - wykrycie spisku opłacanego przez Spartę jest nieco bardziej ekscytujące niż dotarcie do prawdy o sąsiedzkim nieporozumieniu rozstrzygniętym przy użyciu noża w ciemnym zaułku.

27 [Online] https://jakubszamalek.wordpress.com/recenzje (dostęp 31.08.2016). Pozostawiam tu na boku kwestię oceny takich uwag. Nie wiadomo wszak, jak potoczyłyby się 
Bez wątpienia lektura tych uwag byłaby pouczająca dla autorów powieści historycznych i nauczycieli historii, czy jest jednak równie ciekawa dla literaturoznawców, to kwestia otwarta. Niemniej świadczą one o udanej realizacji zamiarów pisarza sformułowanych w paratekstach: jego Grecja czasów Peryklesa jest żywa, a zarazem oswojona i egzotyczna.

W przywoływanym tu kilkakrotnie tekście Paweł Kaczyński, podsumowując swoje uwagi o kryminale historycznym, pisze: „ta historyczna odmiana literatury kryminalnej staje się atrakcyjniejszą dla wielu czytelników wersją powieści historycznej, odświeżając zarówno jej formułę, jak i formułę kryminału"28. Należy jednak pamiętać, że mowa tu o subgatunku powieści kryminalnej - zatem wszystkie jego elementy podporządkowane są atrakcyjności kryminalnej intrygi. Z tego punktu widzenia zręczność w ekshumowaniu martwej przeszłości ${ }^{29}$ jest tylko pochodną atrakcyjności opowieści o tym, jak nieskończona liczba postaci skończyła jako zwłoki w niekończonej liczbie bibliotek, plebanii, komnat, atriów, ze sztyletami, nożami, bełtami sterczącymi im z pleców.

\section{BIB LIOGRA F I A}

Bałus W., Nowy system wiedzy, [w:] Winckelmann J. J., Dzieje sztuki starożytnej, oprac. W. Bałus, przeł. T. Zatorski, Kraków 2012.

Bartoszyński K., O poetyce powieści historycznej, [w:] tenże, Powieść w świecie literackości, Warszawa 1991.

Czubaj M., Etnolog w Mieście Grzechu. Powieść kryminalna jako świadectwo antropologiczne, Gdańsk 2010.

Dominas K., Antyk w kryminale, kryminat w antyku. Steven Saylor i recepcja literatury antycznej, [w:] Literatura kryminalna. Na tropie źródet, red. A Gemra, Kraków 2015.

Izdebska A., hasło kryminał historyczny, "Zagadnienia Rodzajów Literackich" 2016, t. 59, z. 4.

Kaczyński P., Kryminat historyczny - próba poetyki, [w:] Literatura kryminalna. Śledztwo w sprawie gatunków, red. A. Gemra, Kraków 2014.

Koziołek R., Dobrze się myśli literatura, Wołowiec 2016.

Kraska M., Prosta sztuka zabijania. Figury czytania kryminału, Gdańsk 2013.

Picker L., Mysteries of History. Sleuthing through the Past [online] http://www. publishersweekly.com/pw/by-topic/new-titles/adult-announcements/ article/43024-mysteries-of-history.html (dostęp 30.08.2016).

Szamałek J., Czytanie z kości, Warszawa 2015.

Szamałek J., Kiedy Atena odwraca wzrok, Warszawa 2011.

dzieje literatury polskiej, gdyby do Aleksandra Głowackiego dotarł głos, iż „wątek miłości Wokulskiego i Izabeli d...y nie urywa” (fanpage „Recenzje z Lubimy Czytać”; [online] https:// www.facebook.com/RecenzjezLubimyCzytac/?fref=ts). Traktuję jednak te wypowiedzi jako swoisty, żywy i dostępny vox populi.

${ }^{28}$ P. Kaczyński, Kryminat historyczny..., s. 207.

${ }^{29}$ Zob. R. Koziołek, Szkopuł i koniektura, [w:] tenże, Dobrze się..., s. 241. 
Szamałek J., Morze Niegościnne, Warszawa 2013.

Winks R.W., Preface, [w:] The Detective as Historian: History and Art in Historical Crime Fiction, ed. R. B. Browne i L. A. Kreiser, Jr, Bowling Green, 2000.

The Detective as Historian: History and Art in Historical Crime Fiction, ed. R. B. Browne i L. A. Kreiser, Jr, Bowling Green, 2000.

Artykuł stanowi analizę trylogii Jakuba Szamałka, na którą składają się powieści: Gdy Atena odwraca wzrok, Morze Niegościnne i Czytanie z kości. Teksty te rozpatrywane są jako przykład realizacji subgatunku powieści kryminalnej, kryminału historycznego. Rozważania wydobywają cechy charakterystyczne tej konwencji, szczególnie te wynikające $\mathrm{z}$ jej hybrydyczności, a zatem uwikłania w dylematy powieści historycznej: konieczności dokonania wyboru, jak zostaje skonstruowana przeszłość jako jeden z przedmiotów przedstawienia.

\section{Słowa kluczowe}

powieść kryminalna, powieść historyczna, genologia, gatunki literatury popularnej

\section{S U M M A RY}

\section{Crime in old decorations - historical crime novels by Jakub Szamałek}

The article offers an analysis of the trilogy by Jakub Szamałek, which consists of the following novels: When Athena Averts Her Gaze (Gdy Atena odwraca wzrok), The Unwelcoming Sea (Morze Niegościnne) and Reading from Bones (Czytanie z kości). These works are scrutinised as an example of a sub-genre of the crime novel, the historical crime story. The analysis emphasises the typical features of the convention, with particular focus on the hybrid side of its nature, i.e. entanglement in the dilemmas of the historical novel: the necessity to make a choice, and the manner in which the past is structured as one of the constituents of the presentation.

\section{Keywords}

crime novel, historical novel, genology, genres of popular literature 